\title{
Pemberdayaan Ekonomi Masyarakat Melalui Pengembangan Kue Jajanan Pasar Nona Manis
}

\author{
LILI ERTI ${ }^{1}$; MURNAWATI ${ }^{2} ;$ TASRIL $^{3}$ \\ Universitas Lancang Kuning \\ Jln. Yos Sudarso KM 08 Rumbai Telp. (0761) 52581 \\ E-mail : lili3rti@gmail.com
}

\begin{abstract}
Community service activities carried out by the method of delivery of knowledge through counseling and practice. Community service activities are carried out with the method of delivering knowledge about the science of home industry, counseling and delivery of information about home industry, nona manis cake and its benefits, and the way of making nona manis cake, counseling and delivery as well as the practice of making nona manis cake.
\end{abstract}

Keywords: economic improvement and nona manis

Ibu-ibu Kelurahan Rejosari, Kecamatan Tenayan Raya pada umumnya masih memiliki sangat banyak waktu luang setelah mereka selesai mengerjakan pekerjaan rutin rumah tangga. Keterampilan yang mereka miliki untuk mengkreatifitaskan sebuah bahan pangan sangatlah minim karena pengetahuan yang mereka miliki sangatlah sedikit. Melalui kegiatan pengabdian kepada masyarakat yang merupakan salah satu kegiatan tri dharma perguruan tinggi, maka diharapkan dapat memberikan solusi untuk membantu memberikan ilmu kepada masyarakat khususnya ibu-ibu Kelurahan Rejosari, Kecamatan Tenayan Raya.

Salah satu upaya untuk meningkatkan kreativitas dan keterampilan ibu-ibu tersebut adalah dengan membuat dan menjual berbagai jenis jajanan pasar. Kehadiran jajanan pasar terutama yang tradional dan sehat mampu memberi solusi sebagai jajanan pasar yang memiliki permintaan yang tinggi sehingga dapat memberikan peluang potensial apalagi jika dapat dikembangkan. Salah satu jajanan pasar yang potensial adalah kue nona manis.

Kue nona manis merupakan salah satu jajanan tradisional yang melegenda. Kue ini memiliki tekstur yang lembut dengan rasa manis yang menggoda. Banyak yang menyebut bahwa kue ini merupakan salah satu jenis olahan kue talam. Namun tekstur kue nona manis lebih lembut di banding kue talam karena dalam adonannya mengandung telur dan dikocok seperti ketika akan membuat bolu.

Cara membuat kue nona manis tentu saja sangat mudah dan praktis. Bahan-bahan yang dibutuhkan juga terjangkau dimana-dimana dengan harga yang cukup ekonomis. Jadi siapa saja dapat membuat kue nona manis, bahkan bagi pemula sekali pun. Enak dan lembutnya kue berwarna hijau ini membuat banyak orang jatuh hati dan merupakan jajanan pasar favorit. Selain itu, kue nona manis sering disajikan di acara-acara special dan tertentu seperti kudapan ulang tahun, arisan, snak box serta hajatan seperti pernikahan dan khitanan.

Untuk itu kegiatan ini memiliki potensi besar dalam meningkatkan ilmu pengetahuan dan kesejahteraan masyarakat melalui pembuatan kue manis sebagai jajanan pasar dan mampu untuk meningkatkan pendapatan perkapita keluarga sehingga mampu memberi kontribusi dalam memenuhi kebutuhan sehari-hari.

Berdasarkan analisis situasi, maka diperlukan peluang usaha untuk meningkatkan kemampuan kewirausahaan warga. Salah satu peluang usaha yang 
dapat dilakukan adalah pembuatan kue nona manis. Pengenalan makanan tradisional sebagai jajanan pasar diharapkan mampu meningkatkan ekonomi masyarakat, selain itu jajanan pasar yang sehat mempunyai andil besar dalam mengatasi masalah gizi yang terjadi di masyarakat.

Kue nona manis merupakan salah satu jajanan tradisional yang melegenda. Kue ini memiliki tekstur yang lembut dengan rasa manis yang menggoda. Banyak yang menyebut bahwa kue ini merupakan salah satu jenis olahan kue talam. Namun tekstur kue nona manis lebih lembut di banding kue talam karena dalam adonannya mengandung telur dan dikocok seperti ketika akan membuat bolu.

Cara membuat kue nona manis tentu saja sangat mudah dan praktis. Bahanbahan yang dibutuhkan juga terjangkau dimana-dimana dengan harga yang cukup ekonomis. Jadi siapa saja dapat membuat kue nona manis, bahkan bagi pemula sekali pun. Enak dan lembutnya kue berwarna hijau ini membuat banyak orang jatuh hati dan merupakan jajanan pasar favorit. Selain itu, kue nona manis sering disajikan di acara-acara special dan tertentu seperti kudapan ulang tahun, arisan, snak box serta hajatan seperti pernikahan dan khitanan.

Dengan meningkatkan keanekaragaman jajanan pasar yang sehat sambil memperkenalkan makanan tradisional ke masyarakat maka tentunya dibutuhkan pengetahuan dan keterampilan bagi ibu-ibu rumah tangga. Oleh karena itu tujuan dari kegiatan ini adalah mengajak dan memotivasi masyarakat di Kelurahan Rejosari, khususnya ibu-ibu rumah tangga yang belum memahami cara pembuatan kue nona manis untuk dilatih yang dapat dijual dan mendapatkan penghasilan. Disamping itu, dengan melakukan pembuatan kue nona manis dengan cara komersial, akan mengurangi tingkat kemiskinan. Dengan demikian, masyarakat dalam hal ini ibu-ibu rumah tangga yang semula menggantungkan hidup kepada kepala keluarga dalam mencari nafkah, sehingga berimbas pada penurunan pendapatan keluarga, yang hanya bertumpu pada suami sebagai kepala rumah tangga, oleh karena itu melalui pembuatan kue nona manis dapat membantu ekonomi keluarga secara umum.

\section{METODE}

Metode yang digunakan dalam pengabdian pada masyarakat ini adalah :

Penyuluhan

Penyuluhan merupakan cara yang paling baik untuk memberikan pengetahuan kepada masyarakat .Pelaksanaan kegiatan mencakup penyediaan materi yang berkaitan dengan :

- Pemberian informasi tentang pembuatan kue nona manis kepada masyarakat secara keseluruhan.

- Penjelasan bagaimana tahap pelaksanaan proses pembuatan kue nona manis

- Memperkenalkan manfaat dari kualitas produk pembuatan kue nona manis yang dihasilkan, merupakan salah satu jajanan pasar yang sehat.

- Pembagian materi pengabdian ini dilakukan sebelum penyuluhan dimulai, sehingga diharapkan hasil penyuluhan yang maksimal nantinya.

Pelatihan dan Percontohan

Pada kegiatan ini akan diperagakan atau didemonstrasikan bagaimana proses pembuatan kue nona manis. Kegiatan peragaan dilanjutkan dengan pelatihan pada masyarakat.

\section{Diskusi dan Konsultasi}

Pada saat penyuluhan, pelatihan atau percontohan dan pembinaan dilakukan diskusi-diskusi dan konsultasi antara pelaksanaan kegiatan dengan masyarakat tentang pelaksanaan teknologi yang diterapkan dan kendala yang dihadapi, untuk lebih memantapkan hasil kegiatan pengabdian kepada masyarakat ini.

Evaluasi

Evaluasi kegiatan ini dilakukan dengan penyebaran kuisioner, sehingga 
dapat diketahui tingkat pemahaman peserta pada kegiatan pengabdian kepada masyarakat ini.

\section{HASIL}

Hasil wawancara dengan masyarakat setempat dan peserta pelatihan, kue nona manis ini dapat menjadi peluang usaha terutama usaha jajanan pasar yang dapat dilirik dalam pengembangan industry rumah tangga sebagai sebuah peluang usaha.. Adapun hasil kuisioner yang telah diisi oleh peserta kegiatan pengabdian masyarakat, seperti pada tabel berikut ini:

Tabel 1. Hasil Kuesioner Kegiatan Pengabdian kepada Masyarakat

\begin{tabular}{|l|l|l|l|l|}
\hline \multirow{2}{*}{ No } & $\begin{array}{l}\text { Komponen } \\
\text { Kuesioner }\end{array}$ & \multicolumn{3}{|c|}{ Alternatif Jawaban } \\
\cline { 2 - 5 } & $\begin{array}{l}\text { T } \\
\text { mengetahuan } \\
\text { kewgenai } \\
\text { dan peluang } \\
\text { usaha }\end{array}$ & $40 \%$ & - & $60 \%$ \\
\hline 2. & $\begin{array}{l}\text { Pengetahuan } \\
\text { cara pembuatan } \\
\text { kue nona manis }\end{array}$ & $75 \%$ & - & $25 \%$ \\
\hline 3. & Praktek & - & - & $100 \%$ \\
\hline 4. & $\begin{array}{l}\text { Pengetahuan } \\
\text { narasumber/ } \\
\text { pelaksana } \\
\text { kegiatan }\end{array}$ & - & - & $100 \%$ \\
\hline 5. & $\begin{array}{l}\text { Minat peserta } \\
\text { untuk } \\
\text { mengembangkan } \\
\text { kue nona manis }\end{array}$ & $10 \%$ & $15 \%$ & $75 \%$ \\
\hline
\end{tabular}

Ket: $\mathrm{T}=$ Tidak, $\mathrm{N}=$ Netral, $\mathrm{Y}=\mathrm{Ya}$

Sumber: Data Olahan, 2018

Dari rekapitulasi kuisioner diatas maka dapat diketahui bahwa terjadi peningkatan pengetahuan peserta kegiatan mengenai kewirausahaan dan peluang usaha mandiri meningkat dimana peserta yang pada awalnya hanya $60 \%$ saja yang mengetahui menjadi $100 \%$ mengetahui dan memahami mengenai kewirausahaan. Sedangkan pengetahuan mengenai pembuatan kue nona manis meningkat menjadi 100\%, dari awalnya hanya $25 \%$ saja yang mengetahuinya. Sedangkan $100 \%$ peserta mengetahui dan memahami proses pembuatan kue nona manis melalui praktek langsung yang didampingi oleh tim pelaksana kegiatan pengabdian. Dan $75 \%$ peserta kegiatan pengabdian berminat untuk menjadikan kue nona manis ini sebagai peluang usaha mandiri.

\section{PEMBAHASAN}

Proses kegiatan pengabdian dilakukan dengan cara demonstrasi dan ceramah, dimana ceramah dilakukan unmtuk menampaikan informasi tentang kewirausahaan dan peluang usaha serta dan cara pembuatan kue nona manis. Secara garis besar hasil kegiatan yang telah dicapai dalam pengabdian masyarakat ini adalah sebagai berikut:

1. Materi kegiatan, mengenai kewirausahaan dan peluang usaha serta dan cara pembuatan kue nona manis pada umumnya dapat dterima dan dapat dipahami serta mendapat respon dari peserta yang ditandai dengan adanya pertanyaan-pertanyaan yang muncul.

2. Berdasarkan sikap dan pertanyaan yang diajukan dapat diketahui bahwa materi pengabdian sangat membantu dalam peningkatan pengetahuan masyarakat.

3. Dari hasil pengabdian ini diharapkan nantinya akan ada tindak lanjut.

4. Berdasarkan evaluasi dapat diketahui bahwa pada umumnya peserta pengabdian telah memahami tentang kewirausahaan dan peluang usaha serta dan cara pembuatan lavitrap serta manfaatnya dalam meningkatkan perekonomian keluarga.

Hasil penelitian ini sejalan dengan pendapat Novita, N. (2016) bahwa melalui berbagai upaya kreatif ibu-ibu rumah tangga dapat menghadapi kondisi ekonomi yang sedang dialaminya saat ini. 


\section{SIMPULAN}

Kegiatan terlaksana sesuai dengan tujuan dan rencana. Pada penyelenggaraan kegiatan ini dapat diketahui bahwa ada peningkatan pengetahuan peserta mengenai kewirausahaan dan peluang usaha serta dan cara pembuatan kue nona manis. Program atau kegiatan ini sangat efektif dalam penerapan ilmu pengetahuan dan teknologi bagi masyarakat. Dengan metode yang yang sederhana, pembuatan kue nona manis dapat meningkatkan peluang usaha masyarakat. Selain itu pembuatan kue nona manis dapat dijadikan sebagai sumber penghasilan dalam rangka meningkatkan penghasilan masyarakat.

Berdasarkan pengamatan yang diperoleh dari kegiatan ini, maka perlu dilanjutkan dengan pembinaan yang berkesinambungan dan memberi pembekalan mengenai teknik pemasaran.

\section{DAFTAR RUJUKAN}

Busono, T, 2014, Konsep Dasar Kewirausahaan dan Wirausaha, http://silabus.upi.edu/Direktori/FPT K/Teknik_Arsitektur_Perumahan_( D3)/WIRAUSAHA\%20MATERI\% 20terbaru.doc. Diakses pada tanggal 4 September 2015

Herjanto Eddy.(1999). Manajemen Produksi dan operasi. Edisi Kedua. Penerbit PT. Gramedia Widiasarana Indonesia, Jakarta.

Kotler, P. (1997). Manajemen Pemasaran. Diterjemahkan oleh Hendra Teguh dari Buku Marketing Management 9th Ed. Jakarta: Prenhallindo

Novita, N. (2016). Analisis Kreatifitas Kelompok Masyarakat Menghadapi Kondisi Ekonomi Rumah Tangga. Jurnal Daya Saing,2(2), 150-159.

Susanto, T dan B. Saneto. Teknologi Pengolahan Hasil Pertanian.
Surabaya, Indonesia. Winano, F.G., 1993. Pangan, Gizi, Teknologi dan Konsumen. Gramedia Pustaka Utama, Jakarta.

Sudarto, Y. 2000. Budidaya Waluh. Kanisius, Yogyakarta. 